\title{
PROGRAM PEMBERDAYAAN EKONOMI KELUARGA MELALUI PELATIHAN PEMBUATAN KERUPUK ANEKA RASA DARI AMPAS TAHU DI DESA TANJUNG SARI TIMUR KECAMATAN MANGARAN KABUPATEN SITUBONDO
}

\author{
THE FAMILY ECONOMIC EMPOWERMENT PROGRAM THROUGH \\ TRAINING ON MAKING VARIOUS KIND OF FROM TOFU CRACKERS IN \\ TANJUNG SARI TIMUR VILLAGE MANGARAN SITUBONDO DISTRICT
}

\author{
Rini Kartika Sari ${ }^{\left({ }^{*}\right)}$ Afri Prayudi ${ }^{2)}$ Romi Anasrullah $^{3)}$ \\ ${ }^{1,2,3}$ Universitas Abdurachman Saleh Situbondo \\ 1email: rinikartika1903@gmail.com
}

\begin{abstract}
Abstrak: Kabupaten Situbondo adalah salah satu daerah di Provinsi Jawa Timur. Situbondo juga merupakan salah satu pusat UMKM yang memproduksi produk kerajinan. Persaingan yang tinggi membuat para pelaku bisnis UMKM dituntut untuk selalu berinovasi dan perlu ada strategi khusus yang dapat menciptakan kekuatan dalam persaingan. Peserta terdiri dari ibu-ibu dari Kelompok Masyarakat Desa Tanjung Sari Timur. Masalah yang ditemukan dan solusi yang ditawarkan melalui program kemitraan masyarakat (PKM) ini adalah, pertama, kurangnya pengetahuan tentang prinsip-prinsip efisiensi dan efektivitas dalam produksi suatu produk, inovasi dalam kewirausahaan adalah faktor utama dalam melaksanakan pelatihan yang bertujuan untuk meningkatkan ekonomi kelompok masyarakat Tanjung Sari. Yang kedua adalah kurangnya pemahaman tentang dunia wirausaha. Ketidakmampuan memahami dunia bisnis dapat menghambat kemajuan bisnis, sehingga orang cenderung tidak memahami nilai jual produk olahan yang telah berinovasi menjadi lebih baik yang bertujuan meningkatkan ekonomi keluarga dengan lebih baik. Hal ini membuat pelaksana melakukan pelatihan pembuatan berbagai jenis kerupuk untuk diperkenalkan jika ampas tahu yang sudah diolah akan menghasilkan produk yang memiliki nilai jual yang baik di masyarakat Situbondo.
\end{abstract}

Kata Kunci: Ampas Tahu, Kewirausahaan, Ekonomi Keluarga

\begin{abstract}
Situbondo Regency is one of the areas in East Java Province. Situbondo is also one of the UMKM centers producing handicraft products. High competition makes the MSME business people are required to always innovate and there needs to be special strategies that can create strength in competition. Partners consist of mothers from the Tanjung Sari Timur Village Community Group. The problems found and solutions offered through this community partnership program (PKM) are, firstly, the lack of knowledge of the principles of efficiency and effectiveness in the production of a product, innovation in entrepreneurship is a major factor in carrying out training aimed at improving
\end{abstract}




\section{INTEGRITAS : Jurnal Pengabdian}

the economy of Tanjung Sari community groups. The second is the lack of understanding of the entrepreneurial world. The inability to understand the business world can hamper business progress, so that people tend to not understand the selling value of processed products that have been innovated for the better which aims to improve the family economy better. This makes the executor conduct training in making various kinds of dregs crackers to introduce if the tofu dregs that have been processed will produce products that have a good selling value in the Situbondo community.

Keywords:Tofu Dregs, Entrepreneurship, Family Economy

\section{PENDAHULUAN}

Industri yang bergerak pada pengolahan kacang kedelai salah satunya adalah industri tahu. Industri tersebut merupakan industri yang cukup banyak berdiri di wilayah Situbondo dengan bentuk usaha Home Industry. Pada umumnya tahu dijual langsung setelah proses produksi selesai dilakukan, atau dapat dikatakan dijual mentah tanpa proses pematangan lebih lanjut, dan hasil penjualan industri tersebut hanya berasal dari penjualan tahu. Penggunaan ampas tahu masih sangat terbatas bahkan sering sekali menjadi limbah yang tidak termanfaatkan sama sekali (Winarno, 2003:65). Namun yang dapat menjadi perhatian dari industri ini adalah hasil samping produksi tersebut. Dari keseluruhan industri tahu tersebut selain menghasilkan produk jadi yang bernilai ekonomis, tentunya industri tersebut menghasilkan limbah yang berbentuk padat (ampas) maupun cair (sari kedelai hasil pemerasan) disetiap akhir proses produksinya.

Fenomena yang terjadi adalah, kedua limbah yang dihasilkan tidak jarang hanya menjadi sampah sisa produksi tidak bernilai, atau hanya menjadi limbah industri yang langsung dibuang ke lingkungan. Limbah ampas tahu yang biasanya dijual murah dan untuk pakan ternak, kini bisa dimanfaatkan menjadi produk kerupuk ampas tahu (Pratiwi dan Pravasanti:2019). Sedikit jumlahnya dari limbah tersebut yang dimanfaatkan untuk hal lain seperti pakan ternak dan bahkan pengolahan limbah padat dari industri tahu yang berupa ampas tahu menjadi 


\section{INTEGRITAS : Jurnal Pengabdian}

Vol 4, No 1, Juli 2020

ISSN $2580-7978$ (cetak) ISSN $2615-0794$ (online)

produk pangan yang bernilai lebih ekonomis masih sangat jarang dikembangkan. Ampas tahu merupakan limbah tahu yang dihasilkan dari sisa pengolahan kedelai menjadi tahu (Sandi dan Amyesti:2012).

Pengolahan ampas tahu untuk bahan pangan (makanan) dapat meningkatkan program pemerintah dalam membantu meningkatkan gizi masyarakat pada. Ampas tahu yang berkadar air tinggi sisa pembuatan tahu menjadi sarang bakteri jika dibuang ditempat lembab dan berair, disertai bau khas sehingga menimbulkan pencemaran lingkungan dan berpengaruh negatif pada kelestarian lingkungan hidup. Pencemaran lingkungan tersebut dapat dicegah dengan memanfaatkan limbah sebaik-baiknya (Handasari, 2010:35). Menurut Rahayu (2012) yang dikutip oleh Wati (2013) ampas tahu basah dalam per 100 gram mengandung Karbohidrat 11,07\%, Protein 4,71\%, Lemak 1,94\% dan Abu 0,08\%. Oleh karena itu ampas tahu perlu dioptimalkan pemanfaatannya sebagai bahan pangan campuran atau subtitusi pada bahan pangan dasar pada olahan makanan

Ampas tahu dapat dikembangkan lebih lanjut menjadi produk pangan bergizi untuk meningkatkan nilai ekonomis limbah, meningkatkan pendapatan industri tahu, atau membuka usaha home industry pengolahan ampas tahu, dan juga dapat meminimalisir pembuangan limbah padat pada indutri tahu, tetapi ada juga yang dijual setelah diolah menjadi makanan yang siap untuk dikonsumsi secara langsung atau kerupuk tahu (Sediaoetama, 2004:78). Adapun produk yang akan diangkat dalam penulisan ini adalah pengolahan ampas tahu menjadi jajanan ringan (snack) berupa kerupuk ampas tahu dengan berbagai varian rasa.

Tujuan kegiatan ini adalah meningkatkan pengetahuan tentang pemanfaatan ampas tahu menjadi olahan kerupuk aneka rasa dan diharapkan adanya keberlanjutan pembuatan kerupuk aneka rasa dari ampas tahu setelah pelatihan usai guna menunjang menambah pendapatan. Untuk itu agar pemahaman masyarakat akan pentingnya serat pangan dalam pola konsumsi makanan di Indonesia menjadi meningkat,maka karya ilmiah tentang serat pangan dan manfaatnya menjadi penting untuk disampaikan (Alsuhendra dan Santosa, 2011). 


\section{METODE PELAKSANAAN}

Pelaksanaan kegiatan Sistem Pemberdayaan Masyarakat Dalam Hal pelatihan pembuatan olahan ampas tahu Desa Tanjung Sari Timur, Kabupaten Situbondo terdiri dari beberapa rangkaian kegiatan sebagaimana yang tertera di bawah ini:

Tabel 1. Rangkaian Pelaksanaan Kegiatan

\begin{tabular}{|c|l|l|l|}
\hline No. & \multicolumn{1}{|c|}{ Kegiatan } & \multicolumn{1}{|c|}{ Isi } & \multicolumn{1}{c|}{ Keterangan } \\
\hline 1. & Persiapan Pelatihan & $\begin{array}{l}\text { Terdiri dari berbagai } \\
\text { aktivitas: }\end{array}$ & $\begin{array}{l}\text { Dilaksanakan oleh } \\
\text { tim }\end{array}$ \\
$\begin{array}{l}\text { Survei tempat pelaksanaan } \\
\text { kegiatan } \\
\text { Pembuatan proposal dan } \\
\text { penyelesaian administrasi }\end{array}$ & \\
\hline 2. & $\begin{array}{l}\text { Pelatihan dalam } \\
\text { membuat olahan } \\
\text { ampas tahu }\end{array}$ & $\begin{array}{l}\text { a) Penjelasan secara detail } \\
\text { tentang manfaat ampas } \\
\text { tahu } \\
\text { b) Pelatihan cara membuat } \\
\text { olahan ampas tahu }\end{array}$ & $\begin{array}{l}\text { Dilaksanakan oleh } \\
\text { tim }\end{array}$ \\
\hline 3. & $\begin{array}{l}\text { Monitoring dan } \\
\text { Evaluasi }\end{array}$ & $\begin{array}{l}\text { Monitoring dan evaluasi } \\
\text { dalam pengembangan } \\
\text { kegiatan pelatihan pembuatan } \\
\text { ampas tahu. }\end{array}$ & $\begin{array}{l}\text { Dilaksanakan oleh } \\
\text { tim }\end{array}$ \\
\hline
\end{tabular}

\section{HASIL DAN PEMBAHASAN}

\section{Pendampingan Proses Pelatihan}

Masyarakat yang hadir dalam pelatihan pembuatan kerupuk aneka rasa dari ampas tahu, dimana pada mulanya mereka tidak mengetahui ampas tahu dapat dijadikan olahan yang memiliki nilai jual tinggi. Dari sini juga peneliti memberikan pelatihan tentang pembuatan dan sekaligus cara kiat berwirausaha dengan benar. 


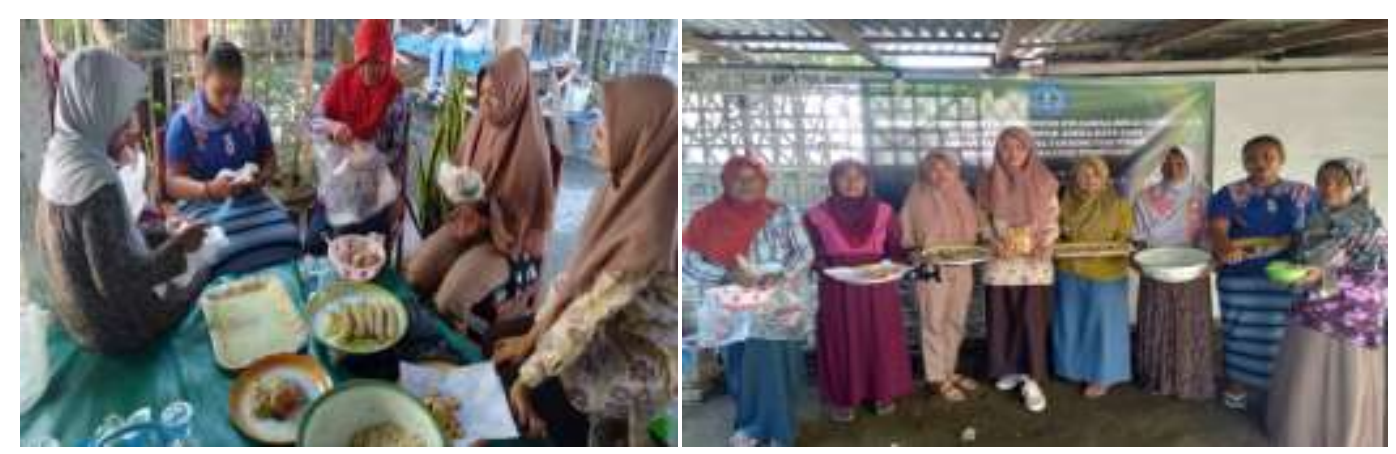

Gambar 1. Peserta Pelatihan Mengikuti Proses Pembuatan Kerupuk Ampas Tahu

Untuk pembuatan olahan kerupuk aneka rasa dari ampas tahu dilakukan dengan langkah-langkah berikut:

\section{Persiapan pemilihan Bahan yang akan digunakan}

Memilih bahan baku harus disesuaikan dengan kebutuhan dalam proses pembuatan kerupuk aneka rasa dari ampas tahu. Adapun bahan-bahan yang digunakan adalah sebagai berikut :
a. Ampas tahu
b. Tepung tapioka
c. Minyak goreng
d. Garam
e. Cabai
f. Bawang merah
g. Bawang putih

\section{Persiapan Peralatan Produksi}

Pemilihan alat produksi sangatlah penting untuk setiap proses produksi, beberapa peralatan yang dibutuhkan dalam pelatihan pembuatan kerupuk aneka rasa dari ampas tahu, yaitu :
a. Pisau
b. Kompor
c. Wajan
d. Spatula 
e. Penyaring

f. Wadah

\section{Proses Cara Pembuatan}

a. Pengukusan pada ampas tahu

Ampas tahu diperas untuk mengurangi kadar air yang ada di ampas tahu. Pemerasan dilakukan secara manual yaitu dengan menggunakan tangan yang diperaspada alat penyaring. Setelah itu, ampas tahu dikukus selama 30 menit.

b. Persiapan bumbu-bumbu

Bumbu-bumbu yang akan digunakan yaitubawang merah, bawang putih, dan garam diulek sampai halus.

c. Proses pengadonan

Ampas tahu yang telah dikukus dicampur dengan tepung tapioka dan bumbu, kemudian diaduk sampai rata. Adonan ini dibentuk seperti silinder dengan diameter 5-6 cm dan panjang $15 \mathrm{~cm}$. Adonan yang telah dibentuk ini disebut dengan istilah dodolan.

d. Proses pengukusan dodolan

Dodolan dikukus selama kurang lebih 2 jam sampai bagian tengah dodolan menjadi matang.

e. Proses pendinginan dodolan

Dodolan yang sudah dikukus diangkat dan didinginkan kurang lebih sampai 20 menit.

f. Proses pengirisan

Dodolan diiris tipis-tipis dengan tebal 2-3 $\mathrm{mm}$. Hasil pengirisan disebut dengan kerupuk basah.

g. Proses penjemuran

Kerupuk basah dijemur dibawah sinar matahari dengan menggunakan wadah sampai kerupuk menjadi kering selama 1 hari. 


\section{INTEGRITAS : Jurnal Pengabdian}

h. Tahap terakhir

Apabila kerupuk sudah dikeringkan selama 1 hari maka kerupuk tersebut sudah bisa digoreng dan di kemasan.

\section{Hasil Produk dan Kemasan}

Setelah proses pembuatan kerupuk selesai pada tahap terakhir produk dikemas semenarik mungkin yang bertujuan untuk menambah nilai jualnya ketika sudah dipasarkan.

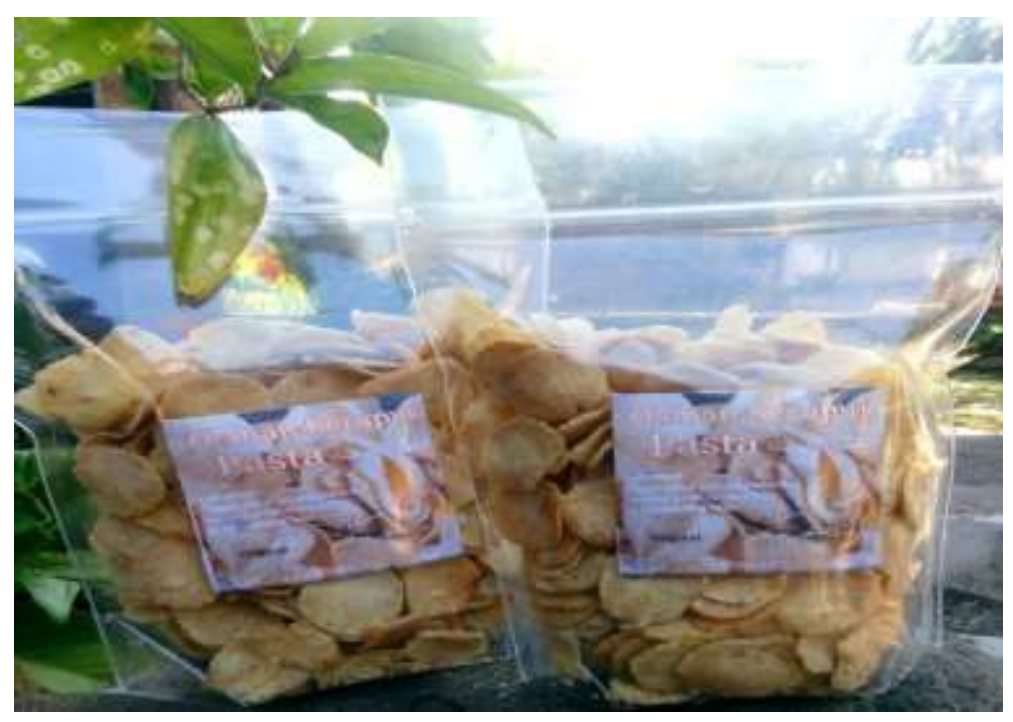

Gambar 2. Hasil Produk

\section{Ketercapaian Target Luaran}

Dalam pelatihan pembuatan olahan kerupuk ampas tahu tentunya berbagai tanggapan bahwasanya produk olahan ini akan menghasilkan laba yang sangat sedikit dikarenakan dilihat dari segi bahannya berupa ampas tahu. Sehingga dapat diidentifikasi permasalahan, diantaranya minimnya informasi tentang pembuatan olahan ampas tahu menjadi makanan (snack) bergizi yang memiliki nilai ekonomis yang sangat tinggi jika diolah secara optimal.Luaran yang telah dicapai dari kegiatan pengabdian ini adalah berupa: 


\section{INTEGRITAS : Jurnal Pengabdian}

1. Meningkatkan pengetahuan tentang pemanfaatan ampas tahu menjadi olahan kerupuk aneka rasa.

2. Diharapkan adanya keberlanjutan pembuatan kerupuk aneka rasa dari ampas tahu setelah pelatihan usai guna menunjang menambah pendapatan.

3. Artikel Ilmiah/Publikasi.

\section{KESIMPULAN}

Kegiatan ini merupakan pembinaan dalam bentuk produksi dan pemasaran produk olahan ampas tahu. Minimnya pengetahuan para pelaku usaha untuk bisa menghasilkan produk berkualitas. Pembinaan ini dilakukan dengan cara melakukan pelatihan pembuatan olahan kerupuk aneka rasa dari ampas tahu kepada kelompok masyarakat Desa Tanjung Sari Timur. Luaran yang dihasilkan dari kegiatan ini adalah Meningkatkan pengetahuan tentang pemanfaatan ampas tahu menjadi olahan kerupuk aneka rasa. Diharapkan adanya keberlanjutan pembuatan kerupuk aneka rasa dari ampas tahu setelah pelatihan usai guna menunjang menambah pendapatan yang dapat meningkatkan kesejahteraan keluarga masyarakat yang ada di Desa Tanjung Sari Timur.

\section{DAFTAR PUSTAKA}

Alsuhendra, Ridawati, dan A. I. Santoso. 2011. Pengaruh Penggunaan Edible Coating Terhadap Susut Bobot, Ph, dan Karakteristik Organoleptik Buah Potong Pada Penyajian Hidangan Dessert. Skripsi. Teknik Universitas Negeri Jakarta.

Handasari, E., Ali R., Juju W. 2010. "Hubungan Pendidikan dan Pengetahuan Gizi Ibu Dengan Tingkat Konsumsi Energi dan Protein Anak TK Nurul Bahri Desa Wukir Sari Kecamatan Batang Kabupaten Batang”. Jurnal Kesehatan Masyarakat Indonesia, 6 (2).

Pratiwi, Desi Nur dan Pravasanti, Yuwita Ariessa. 2019. "Inovasi Kerupuk Tepung Ampas Tahu Guna Peningkatan Pendapatan Ibu-Ibu Purwogondo, Kartasura”. Jurnal Budimas, 1 (1). 
Sandi, S., R. Palupi Dan Amyesti. 2012. "Pengaruh Penambahan Ampas Tahu dan Dedak Fermentasi Terhadap Karkas, Usus dan Lemak Abdomen Ayam Broiler". Jurnal Fakultas Pertanian Universitas Sriwijaya, Sumatra Selatan $2(1)$.

Sediaoetama , Achmad Djaeni. 2004. Ilmu Gizi untuk Mahasiswa dan Profesi. Edisi kelima. Jakarta : Dian Rakyat.

Wati, Dwi Setiana, Rukmanasari Dwi Prasetyani. 2013. Pembuatan Biogas dari Limbah Cair Industri Bioetanol Melalui Proses Anaerob (Fermentasi). Universitas Diponegoro : Semarang.

Winarno, F.G. 2003. Kimia Pangan dan Gizi. Jakarta: PT Gramedia Pustaka Utama. 